\title{
ANALISIS YURIDIS PENDEKATAN KOMPERATIF DALAM ANTROPOLOGI HUKUM MENURUT PARA AHLI
}

\author{
Nama : Elvi Yenita \\ Email : elvy75yenita@gmail.com \\ BP : 2110003600092 \\ Kelas : $1 \mathrm{H} 3$ \\ Universitas Ekasakti Padang
}

\section{A. PENDAHULUAN}

Indonesia adalah Negara hukum, sebagaimana ditegaskan dalam ketentuan Pasal 1 ayat (3) Undang-Undang Dasar Negara Republik Indonesia Tahun 1945 (UUD 1945). Sebagai negara hukum Indonesia menganut konsepsi welfare state (negara kesejahteraan), sebagaimana diisyaratkan dalam alinea keempat Pembukaan UUD 1945, yang merupakan tujuan negara. Negara hukum pada dasarnya bertujuan untuk memberikan perlindungan hukum bagi rakyat. Perlindungan hukum bagi rakyat terhadap tindakan pemerintahan dilandasi oleh dua prinsip; prinsip hak asasi manusia dan prinsip negara hukum. Setiap penyelenggaraan urusan pemerintahan haruslah berdasarkan pada aturan hukum yang berlaku. Sebagai konsekuensi dari negara hukum, wajib adanya jaminan bagi administrasi negara sebagai alat perlengkapan negara untuk dapat menjalankan pemerintahan dan warga negara memiliki hak dan kewajiban mendapat jaminan perlindungan.

Hukum adalah segala aturan yang mengatur tingkah laku manusia di dalam masyarakat yang dibuat oleh badan resmi yang bersifat memaksa dan mempunyai sanksi yang tegas, Jadi, Sumber Hukum adalah segala sesuatu yang menimbulkan atau melahirkan hukum sedangkan antropologi mempelajari manusia baik dari segi fisik maupun budaya 
antropologi hukum adalah mempelajari hukum sebagai salah satu aspek kebudayaan. Antropologi hokum adalah ilmu yang mempelajari kehidupan manusia dan kebudayaan di bidang hukum atau ilmu yang mempelajari kaidah social yang bersifat hokum.

\section{B. PEMBAHASAN}

Pengertian Komparatif adalah dengan cara membandingkan dengan penjelasan berdasarkan perbandingan hukum, agar dapat ditemukan kejelasan suatu ketentuan UU. Pengertian Teori Menurut Umum dan Ahli Menurut Kamus Hukum, kata yuridis berasal dari kata Yuridisch yang berarti menurut hukum atau dari segi hukum. Dapat disimpulkan tinjauan yuridis berarti mempelajari dengan cermat, memeriksa (untuk memahami), suatu pandangan atau pendapat dari segi hukum, dan ada juga pengertian yuridis menurut para ahli adalah segala hal yang mempunyai arti hukum dan telah disahkan oleh pemerintah. Nah, jika aturan tersebut dilanggar, maka siapapun yang melanggarnya akan mendapatkan sanksi. Yuridis ini sifatnya adalah memaksa. Maksudnya yaitu seseorang haruslah mematuhinya. Selain itu menurut para ahli lainnya yaitu segala hal yang mempunyai arti hukum dan telah disahkan oleh pemerintah. Nah, jika aturan tersebut dilanggar, maka siapapun yang melanggarnya akan mendapatkan sanksi. Yuridis ini sifatnya adalah memaksa. Maksudnya yaitu seseorang haruslah mematuhinya.

Ada tujuh periode penting dalam perkembangan antropologi hokum menurut para ahli

1. Periode yang pertama terjadi pada tahun 1860 -an ketika Sir Henry Maine yang sedang bertugas di India menerbitkan Ancient Law yang merangkum berbagai tradisi hukum dan mengembangkan teori bahwa setiap masyarakat yang berkembang akan 
mengalami perubahan dari versi primitifnya menuju masyarakat Victoria. Pandangan Maine tentu dapat dicap rasis dalam konteks modern karena memuliakan peradaban Eropa. Sedangkan pada tahun 1861 ia dipandang sebagai peletak dasar studi antropologis tentang hokum melelui teori yaitu tentang masyarakat dan hukum menyatakan hukum berkembang seiring dan sejalan dengan perkembangan masyarakat dari masyarakat sederhana, primitive, tradisional dan kesukuan atau tribal ke masyarakat yang kompleks dan modern.

2. Periode kedua terjadi pada tahun 1920 -an ketika Bronislaw Malinowski mengkritik teori Maine dan mengembangkan pendekatan etnografis dalam mengkaji hukum. E. Adamson Hoebel bersama dengan akademisi hukum Karl Llewelyn menerbitkan The Cheyenne Way pada tahun 1941 yang menggunakan pendekatan studi kasus dalam mengkaji hukum asing. Pendekatan Hoebel ini merupakan kembalinya teori evolusi yang dikembangkan oleh Maine.

3. Di pertengahan abad ke-20, antropolog-antropolog memperdebatkan penggunaan pendekatan pengkategorian hukum Anglo-Amerika dalam mengkaji masyarakatmasyarakat non-Barat. Dua tokoh utama dalam perdebatan ini ialah Max Gluckman dan Paul Bohannan. Bohannan meyakini bahwa pengkategorian berdasarkan hukum Anglo-Amerika membatasi pemahaman dan keterwakilan budaya lain dan lebih menyukai penggunaan istilah setempat yang belum tentu konsepnya dapat diterjemahkan ke dalam bahasa Inggris tetapi dapat dijelaskan. Sementara itu Gluckman menilai pendekatan Bohannan tersebut terlalu berhati-hati dan justru menjadi penghalang dalam menghasilkan analisis perbandingan. 
4. Pada tahun 1970-an, kajian antropologi hukum mengalami peralihan dari aturan hukum ke proses hukum. Gagasan pengkajian proses hukum ini melihat pluralisme hukum, rezim alternatif, dan struktur hukum yang ada dalam masyarakat mana pun.

5. Pada 1980-an, wacana dan kritik pascamodernis muncul dan mempertanyakan pengkategorian tradisional yang dilakukan oleh para antropolog hukum. Pendekatan kasus yang dikembangkan oleh Hoebel dianggap tidak melihat kepatuhan pada hukum di masyarakat dan penekanan pada nilai-nilai hukum Anglo-Amerika.

6. Pada tahun 1990-an, pengkajian antropologi hukum terus berkembang dengan banyaknya akademisi yang menginginkan kajian dari perspektif-perspektif berbeda seperti melalui pendekatan linguistik, pendekatan naratif, kajian interdisipliner, aspekaspek transnasional, dan keterkaitan antara hukum dengan budaya suatu masyarakat. Sebelum Perang Dunia II, studi antropologi di Indonesia banyak dilakukan oleh para cendekiawan Belanda di universitas-universitas atau institusi lain. Beberapa karya yang dihasilkan adalah penelitian hukum adat oleh C. van Vollenhoven[20] dan J. Prins serta pengembangan materi antropologi Indonesia oleh R. Kennedy, G.J. Held, A.G. Gerbrands, P.E. de Josselin de Jong, dan Koentjaraningrat.

7. Setelah kemerdekaan Indonesia, para antropolog Belanda tidak lagi melanjutkan studinya di Indonesia. Posisi mereka banyak digantikan oleh antropolog dari Amerika Serikat. Hal ini umum mengingat tingginya ketertarikan cendekiawan mereka pada Asia Tenggara pascaperang. Terdapat setidaknya tiga institusi penting di Amerika 
Serikat yang menjadi pusat penelitian antropologi Indonesia, yaitu Universitas Cornell, Institut Teknologi Massachusetts, dan Universitas Yale.

Universitas Indonesia pertama kali membuka antropologi sebagai mata kuliah tambahan di Fakultas Hukum dan di Fakultas Sastra pada awal 1950-an. Semua pengajarnya berkebangsaan Belanda. Pada saat itu, terdapat dua pandangan di antara para akademisi. Yang pertama lebih menyukai sosiologi sementara yang lain lebih menyukai antropologi. Akademisi yang lebih menyukai sosiologi berpendapat bahwa antropologi tidak sesuai untuk negara berkembang dan didasarkan pada kepentingan kolonial. Yang menyukai antropologi menganggap antropologi penting dalam mengamati keragaman kelompok etnik di Indonesia. Pada tahun 1956, dua orang Indonesia yang menimba ilmu antropologi di Belanda dan Amerika Serikat merencanakan pendirian program studi Antropologi di Fakultas Sastra Universitas Indonesia. Mulai tahun ajaran 1983-84, Prodi Antropologi dipindahkan ke Fakultas Ilmu Sosial.

\section{PENUTUP}

Pengertian Komparatif adalah dengan cara membandingkan dengan penjelasan berdasarkan perbandingan hukum, agar dapat ditemukan kejelasan suatu ketentuan UU. Pengertian Teori Menurut Umum dan Ahli Menurut Kamus Hukum, kata yuridis berasal dari kata Yuridisch yang berarti menurut hukum atau dari segi hukum. Dapat disimpulkan tinjauan yuridis berarti mempelajari dengan cermat, memeriksa (untuk memahami), suatu pandangan atau pendapat dari segi hukum, dan ada juga pengertian 
yuridis menurut para ahli adalah segala hal yang mempunyai arti hukum dan telah disahkan oleh pemerintah. Sedangkan menurut Sir Henry Maine mengatakan bahwa sebagai peletak dasar studi antropologis tentang hokum melelui teori yaitu tentang masyarakat dan hukum menyatakan hukum berkembang seiring dan sejalan dengan perkembangan masyarakat dari masyarakat sederhana, primitive, tradisional dan kesukuan atau tribal ke masyarakat yang kompleks dan modern. 


\section{DAFTAR PUSTAKA}

Darmini Roza dan Laurensius Arliman S, Peran Pemerintah Daerah Di Dalam Melindungi Hak Anak Di Indonesia, Masalah-Masalah Hukum, Volume 47, Nomor 1, 2018. https://doi.org/10.14710/mmh.47.1.2018.10-21

Laurensius Arliman S, Peranan Metodologi Penelitian Hukum di Dalam Perkembangan Ilmu

Hukum di Indonesia, Soumatera Law Review, Volume 1, Nomor 1, 201. http://doi.org/10.22216/soumlaw.v1i1.3346.

Laurensius Arliman S, Peran Badan Permusyawaratan Desa di Dalam Pembangunan Desa dan Pengawasan Keuangan Desa, Padjadjaran Journal of Law, Volume 4, Nomor 3, 2017. https://doi.org/10.15408/jch.v4i2.3433.

Laurensius Arliman S, Penanaman Modal Asing Di Sumatera Barat Berdasarkan UndangUndang Nomor 25 Tahun 2007 Tentang Penanaman Modal, Supremasi Hukum, Volume 1, Nomor 1, 2018. http://dx.doi.org/10.36441/hukum.v1i01.102 .

Laurensius Arliman S, Memperkuat Kearifan Lokal Untuk Menangkal Intoleransi Umat Beragama Di Indonesia, Ensiklopedia of Journal, Volume 1, Nomor 1, 2018, https://doi.org/10.33559/eoj.v1i1.18.

Laurensius Arliman S, Perkawinan Antar Negara Di Indonesia Berdasarkan Hukum Perdata Internasional, Kertha Patrika, Volume 39, Nomor 3, 2017, https://doi.org/10.24843/KP.2017.v39.i03.p03.

Laurensius Arliman S, Partisipasi Masyarakat Di Dalam Pengelolaan Uang Desa PascaUndangUndang Nomor 6 Tahun 2014 Tentang Desa, Jurnal Arena Hukum, Volume 12, Nomor 2, 2019, https://doi.org/10.21776/ub.arenahukum.2019.01202.5. 
Laurensius Arliman S, Mewujudkan Penegakan Hukum Yang Baik Di Negara Hukum Indonesia, Dialogica Jurnalica, Volume 11, Nomor 1, 2019, https://doi.org/10.28932/di.v11i1.1831.

Laurensius Arliman S, Mediasi Melalui Pendekatan Mufakat Sebagai Lembaga Alternatif Penyelesaian Sengketa Untuk Mendukung Pembangunan Ekonomi Nasional, UIR Law Review, Volume 2, Nomor 2, 2018,

\section{https://doi.org/10.25299/uirlrev.2018.vol2(02).1587}

Laurensius Arliman S, Peranan Filsafat Hukum Dalam Perlindungan Hak Anak Yang Berkelanjutan Sebagai Bagian Dari Hak Asasi Manusia, Doctrinal, Volume 1, Nomor 2,2016.

Laurensius Arliman S, Ni Putu Eka Dewi, Protection of Children and Women's Rights in Indonesiathrough International Regulation Ratification, Journal of Innovation, Creativity and Change Volume 15, Nomor 6, 2021. Laurensius Arliman S, Gagalnya Perlindungan Anak Sebagai Salah Satu Bagian Dari Hak Asasi Manusia Oleh Orang Tua Ditinjau Dari Mazhab Utilitarianisme, Jurnal Yuridis, Volume 3, Nomor 2, 2016, http://dx.doi.org/10.35586/.v3i2.180.

Laurensius Arliman S, Tantangan Pendidikan Kewarganegaraan Pada Revolusi 4.0, Jurnal Ensiklopedia Sosial Review, Volume 2, Nomor 3, 2020. 